\title{
EVALUASI FAKTOR BEBAN TENAGA LISTRIK PADA FEEDER TRAFO 2 PANAKKUKANG MAKASSAR
}

\author{
Edi Suhardi Rahman ${ }^{1}$, Syacitra Arli $\mathrm{S}^{2}$ \\ ${ }^{1}$ Program Studi Teknik Elektro Universitas Negeri Makassar \\ edisuhardi@unm.ac.id \\ ${ }^{2}$ Program Studi Teknik Elektro Universitas Negeri Makassar \\ syacitra4@gmail.com
}

\begin{abstract}
ABSTRAK
Penelitian ini bertujuan untuk mengetahui besar perubahan faktor beban sektor pelanggan listrik pada saluran distribusi feeder trafo 2 panakkukang untuk mengetahui besar faktor rugi pada feeder trafo 2 panakkukang makassar. Jenis penelitian yang digunakan yaitu deskriptif kuantitatif. Teknik pengumpulan data yang digunakan adalah teknik dokumentasi. Teknik analisis data yang digunakan yaitu melakukan perhitungan menggunakan persamaan faktor beban dan faktor rugi. Hasil penelitian menunjukkan bahwa faktor beban harian selama 4 bulan, yang diperoleh pada penelitian untuk pelanggan rumah tangga beban 450 VA sampai 6600 VA faktor bebannya hampir tetap saja yaitu 30,52\% - 32,50\% atau rata rata $31,11 \%$, pelanggan bisnis yaitu $17,21 \%-21,35 \%$ atau rata rata $18,52 \%$, industri faktor beban yaitu 21,37\% - 22,47\% atau rata rata $21,58 \%$, dan faktor beban pemerintah yaitu $18,87 \%-30,71 \%$ atau rata rata $25,49 \%$. Secara keseluruhan faktor beban harian pada bulan mei sampai agustus 2020, rata rata pemakaian beban listrik oleh pelanggan masih rendah, dimana faktor beban PLN tertinggi baru mencapai 47,5\%. dan maksimal $80 \%$. sedangkan besarnya faktor rugi untuk saluran pelanggan rumah tangga rata rata $17,23 \%$ dan faktor rugi untuk saluran pelanggan bisnis rata rata besarnya $8,35 \%$, untuk pelanggan industri faktor ruginya rata rata $10,63 \%$, dan pelanggan pada pemerintah faktor ruginya rata rata $15,2 \%$. Kesimpulan yang didapatkan bahwa perubahan faktor beban sektor pelanggan listrik pada saluran distribusi feeder trafo 2 panakkukang makassar akan berfluktuasi secara priodik dan masih memenuhi standar operasional yang diperbolehkan, namun makin mendekati faktor beban maksimum.
\end{abstract}

Kata Kunci: Faktor beban, Saluran Distribusi, Pelanggan

\section{EVALUATION OF ELECTRICITY LOAD FACTORS ON FEEDER TRANSFORMERS 2 PANAKKUKANG MAKASSAR}

\begin{abstract}
This study aims to determine the change in the load factor of the electricity customer sector on the distribution channel of the Panakkukang 2 Panakkukang transformer feeder to determine the loss factor in the Panakkukang 2 Panakkukang transformer feeder Makassar. The type of research used is descriptive quantitative. The data collection technique used is the documentation technique. The data analysis technique used is to perform calculations using the load factor equation and the loss factor equation. The results showed that the daily load factor for 4 months, which was obtained in the study for household customers, the load factor was $450 \mathrm{VA}$ to $6600 \mathrm{VA}$, the load factor was almost the same, namely $30.52 \%$ $32.50 \%$ or an average of $31.11 \%$, business customers namely $17.21 \%-21.35 \%$ or an average of $18.52 \%$, the load factor industry is $21.37 \%-22.47 \%$ or an average of $21.58 \%$, and the government burden factor is $18.87 \%-30.71 \%$ or an average of $25.49 \%$. Overall, the daily load factor in May to August 2020, the average electricity usage by customers is still low, where the highest PLN load factor only reached $47.5 \%$. and a maximum of $80 \%$. while the average loss factor for household customer channels is $17.23 \%$ and the average loss factor for business customer channels is $8.35 \%$, for industrial customers the average loss factor is $10.63 \%$, and for government customers the average loss factor is $15.2 \%$. The conclusion is that changes in the load factor of the electric customer sector on the distribution channel of the Panakkukang 2 Panakkukang Makassar distribution feeder will fluctuate periodically and still meet the allowed operational standards, but are getting closer to the maximum load factor.
\end{abstract}

Keyword: Load Factor, Distribution Channel, Customer 


\section{PENDAHULUAN}

Sumber energi listrik merupakan salah satu energi yang tidak bisa dilepaskan dari kehidupan manusia, energi listrik sendiri digunakan untuk memenuhi kebutuhan sehari-hari seperti penerangan, proses produksi yang melibatkan peralatan elektronik dan mesin industri. Sistem penyediaan tenaga listrik terdiri dari beberapa pembangkit yang saling berhubungan antara satu dengan yang lain pada jaringan transmisi dan jaringan distribusi. Sistem jaringan listrik mempunyai tiga bagian utama yaitu pusat pembangkit, saluran transmisi dan saluran distribusi. Saluran distribusi menghubungkan semua beban yang terpisah antara satu dengan yang lain ke saluran transmisi [1].

Secara umum saluran distribusi melayani beban dengan dibagi menjadi beberapa sektor, antara lain sektor rumah tangga, sektor industri, sektor usaha dan sektor komersial. Pada setiap sektor beban mempunyai karakteristik yang berbeda-beda, hal ini berkaitan dengan pola konsumsi energi listrik pada tiap-tiap sektor. Bentuk pola beban listrik yang fluktatif di berbagai sektor menjadi permasalahan pada sistem tenaga listrik, maka perlu adanya karakteristik beban listrik untuk mengetahui permasalahan yang pada sistem tenaga listrik.

Sistem distribusi memiliki tujuan utama yaitu menyalurkan energi tenaga listrik dari gardu distribusi ke pelanggan, oleh karena itu faktor utama dalam perancangan sistem distribusi harus diperhatikan karakteristik diberbagai beban. Karakteristik beban listrik pada suatu gardu distribusi tergantung pada jenis beban yang dilayaninya. Karakteristik beban mempunyai peranan penting dalam menentukan rating peralatan pemutus rangkaian, analisis rugi-rugi dan menentukan kapasitas pembebanan pada suatu gardu distribusi atau gardu induk. Faktor yang menentukan karakteristik beban diantaranya faktor beban, faktor beban harian, faktor beban harian rata-rata dan faktor penilaian beban. Faktor beban merupakan penyederhanaan penting dari suatu data penggunaaan energi listrik dan tergantung pada rasio permintaan rata-rata terhadap permintaan puncak (peak demand) [2].

Jika perusahaan listrik ingin meningkatkan load factor maka perusahaan tersebut harus beroperasi secara maksimal dan memperbaiki sistem operasi. Faktor perhitungan selama 24 jam dapat memperlihatkan rata-rata beban [3]. Faktor beban rata-rata yaitu beban pada pagi hari, siang hari dan sore hari seperti malam hari terjadi beban puncak. Sektor rumah tangga terjadi fluktuasi energi listrik yang cukup besar, dimana fluktuasi tersebut disebabkan karena konsumsi energi listrik dominan pada malam hari. Sektor industri komsumsi energi listrik sepanjang hari, karena pada sektor industri bekerja selama dua puluh empat jam, sehingga fluktuasi konsumsi energi hampir sama dengan perbandingan puncak terhadap beban rata rata sama dengan satu. Beban pada sektor komersial dan sektor usaha mempunyai karakteristik yang hampir sama [4].

\section{METODE PENELITIAN}

Jenis penelitian ini adalah penelitian deskriptif kuantitatif yaitu penelitian berdasarkan jumlah atau banyaknya data yang memuat angka-angka dengan langkah mengevaluasi faktor beban tenaga listrik dan faktor rugi-rugi beban pada feeder Trafo 2 Panakkukang Makassar.

Pada penelitian ini, peneliti melakukan pengumpulan data dengan teknik pengumpulan data dokumentasi. Dokumentasi adalah suatu cara yang digunakan untuk memperoleh data dan informasi dalam bentuk buku, arsip, dokumen, tulisan angka dan gambar yang berupa laporan serta keterangan yang dapat mendukung penelitian [5].

\section{HASIL DAN PEMBAHASAN}

\section{A. Hasil Penelitian}

Berdasarkan data yang ada dalam $\mathrm{kWh}$, maka perhitungan untuk mendapatkan harga $\mathrm{kW}$ perhari dapat dilihat pada Tabel 1.

Hasil dari Tabel 1 menunjukkan besarnya tarif pelanggan PLN rumah tangga R1 450 VA sampai 2200 VA, faktor bebannya $23,43 \%$ sampai $63,30 \%$ dan faktor rugi 10,85\%-47,03\%. R2 3500 VA sampai $5500 \mathrm{VA}$, faktor bebannya $27,20 \%$, faktor ruginya 13,33\%, dan R3 6600 VA, pada tegangan 220/380 volt, faktor bebannya $22,92 \%$, faktor ruginya $10,54 \%$. Ini memberikan pengertian bahwa pada sektor pelanggan rumah tangga tersebut masih memungkinkan untuk penambahan beban pelanggan atau ketersediaan daya PLN. Sedangkan faktor rugi rata rata $18,35 \%$, menunjukkan daya PLN yang tersalur ke pelanggan belum maksimal.

Sektor pelanggan bisnis B1 $450 \quad \mathrm{VA} / 220 \mathrm{~V}$ sampai $5500 \mathrm{VA} / 220 \mathrm{~V}$, mempunyai faktor beban $20,17 \%$ sampai $31,46 \%$, faktor ruginya $8,89 \%$ 16,35\%. B2 6600VA sampai $200 \mathrm{kVA}, 220 \mathrm{~V} / 380 \mathrm{~V}$, faktor bebannya $18,72 \%$, faktor ruginya $8,06 \%$. B3 diatas $200 \mathrm{kVA}$ ke atas, faktor bebannya 13,23\%, faktor ruginya $5,18 \%$. Ini menjelaskan bahwa penambahan daya pelanggan bisnis masih dapat terlayani oleh PLN. Sedangkan faktor rugi rata rata 9,79\%, menunjukkan daya PLN yang tersalur ke pelanggan belum maksimal. 
TABEL 1. GOLONGAN DAYA TIAP-TIAP SEKTOR BEBAN PELANGGAN TARIF LISTRIK BEBAN PERHARI BULAN MEI PADA SALURAN DISTRIBUSI FEEDER TRAFO 2

\begin{tabular}{|c|c|c|c|c|c|c|}
\hline $\begin{array}{c}\text { Tarif } \\
\text { Pelanggan }\end{array}$ & $\begin{array}{l}\text { Teg } \\
\text { (V) }\end{array}$ & $\begin{array}{l}\text { Daya } \\
\text { (VA) }\end{array}$ & $\begin{array}{c}\text { Beban } \\
\text { rata -rata } \\
(\mathbf{k W})\end{array}$ & $\begin{array}{c}\text { Beban } \\
\text { Puncak } \\
(k W)\end{array}$ & $\begin{array}{l}\mathbf{F b} \\
(\%)\end{array}$ & $\begin{array}{c}\mathrm{Fr} \\
(\%)\end{array}$ \\
\hline R.1/450 VA & 220 & 3.421 .800 & $1.841,13$ & $2.908,53$ & 63,30 & 47,03 \\
\hline R.1/900 VA & & 5.255 .100 & $1.589,67$ & $4.466,83$ & 35,58 & 19,52 \\
\hline $\begin{array}{l}\text { R.1 M/900 } \\
\text { VA }\end{array}$ & & 35.227 .800 & $7.018,02$ & $29.943,63$ & 23,43 & 10,85 \\
\hline $\begin{array}{l}\text { R.1/1.300 } \\
\text { VA }\end{array}$ & & 40.978 .600 & $8.959,98$ & $34.831,81$ & 25,72 & 12,33 \\
\hline R. $1 / 2200$ VA & & 30.441 .400 & $7.602,40$ & $25.875,19$ & 29,38 & 14,85 \\
\hline $\begin{array}{c}\text { R.2/3.500 } \\
\text { VA - 5.500 }\end{array}$ & & 18.850 .400 & $4.358,67$ & $16.022,84$ & 27,20 & 13,33 \\
\hline $\begin{array}{l}\text { R.3/6.600 } \\
\text { VA > }\end{array}$ & $\begin{array}{c}220- \\
380\end{array}$ & 8.266 .500 & $1.610,76$ & $7.026,52$ & 22,92 & 10,54 \\
\hline Jumlah R & & 142.441 .600 & $32.980,63$ & $121.075,36$ & & \\
\hline B.1/450 VA & 220 & 12.600 & 3,37 & 10,71 & 31,46 & 16,35 \\
\hline B.1/900 VA & & 548.100 & 108,36 & 465,88 & 23,25 & 10,75 \\
\hline $\begin{array}{l}\text { B.1/1.300 } \\
\text { VA }\end{array}$ & & 1.211 .600 & 219,52 & $1.029,86$ & 21,31 & 9,56 \\
\hline $\begin{array}{c}\text { B. } 1 / 2.200 \\
\text { VA }-5.500 \\
\text { VA }\end{array}$ & & 10.199 .500 & $1.748,72$ & $8.669,57$ & 20,17 & 8,89 \\
\hline $\begin{array}{l}\text { B. } 2 / 6.600 \\
\text { VA }-200 \\
\text { kVA }\end{array}$ & $\begin{array}{c}220- \\
380\end{array}$ & 38.830 .800 & $6.181,45$ & $33.006,18$ & 18,72 & 8,06 \\
\hline $\begin{array}{c}\text { B. } 3 />200 \\
\text { kVA }\end{array}$ & & 35.577 .000 & $4.002,42$ & $30.240,45$ & 13,23 & 5,18 \\
\hline Jumlah B & & 86.379 .600 & $12.263,84$ & $73.422,66$ & & \\
\hline $\begin{array}{c}\text { I. } 1 / 3500 \mathrm{VA} \\
-14 \mathrm{kVA}\end{array}$ & $\begin{array}{c}220- \\
380\end{array}$ & 21.100 & 0,89 & 17,93 & 4,96 & 1,64 \\
\hline $\begin{array}{c}\text { I. } 2 / 14 \mathrm{kVA}- \\
200 \mathrm{kV}\end{array}$ & & 795.500 & 154,14 & 676,17 & 22,79 & 6,83 \\
\hline $\begin{array}{c}\text { I. } 3 />200 \\
\text { kVA }\end{array}$ & & 3.325 .000 & $1.027,81$ & $2.826,25$ & 36,36 & 20,15 \\
\hline Jumlah I & & 4.142 .500 & $1.182,84$ & $3.521,12$ & & \\
\hline P.1/450 VA & 220 & 450 & 0,28 & 382,5 & 0 & 0 \\
\hline P.1/900 VA & & 13.500 & 3,96 & 11,47 & 34,52 & 18,68 \\
\hline P.1/1.300 VA & & 18.200 & 2,74 & 15,47 & 17,71 & 7,50 \\
\hline $\begin{array}{c}\text { P.1/2.200 VA } \\
-5.500 \mathrm{VA}\end{array}$ & & 104.600 & 21,36 & 88,91 & 24,02 & 11,23 \\
\hline $\begin{array}{l}\text { P. } 1 \text { / } 6.600 \\
\text { VA - } 200 \\
\text { kVA }\end{array}$ & $\begin{array}{c}220- \\
380\end{array}$ & 3.568 .500 & 639,73 & $3.033,22$ & 21,09 & 9,42 \\
\hline $\begin{array}{l}\text { P. } 2 />200 \\
\text { kVA }\end{array}$ & & 1.110 .000 & 95,1 & 943,5 & 10,07 & 03,72 \\
\hline $\begin{array}{c}\text { P.3/ 8,66 } \\
\text { MVA }\end{array}$ & & 5.136 .400 & $1.079,13$ & $4.365,94$ & 24,71 & 11,68 \\
\hline Jumlah P & & 9.951 .650 & $1.842,3$ & $8.841,01$ & & \\
\hline
\end{tabular}

Sektor pelanggan industri I1 $3500 \mathrm{VA}-14$ $\mathrm{kVA}$, faktor bebannya $4,96 \%$, faktor ruginya $1,64 \%$, I2 $14 \mathrm{kVA}-200 \mathrm{kVA}$, faktor bebanya $22,79 \%$, faktor ruginya $6,83 \%$, dan I3 di atas 200 $\mathrm{kVA}$, faktor bebannya $36,36 \%$,faktor ruginya $20,15 \%$ pada tegangan $220 / 380 \quad \mathrm{~V}$. Ini menjelaskan pula bahwa penambahan beban pelanggan industri masih memungkinkan oleh PLN. Sedangkan faktor rugi rata rata $9,54 \%$, menunjukkan daya PLN yang tersalur ke pelanggan belum maksimal.

Sektor pemerintah P1 450 VA sampai 5500 $\mathrm{VA} / 220 \mathrm{~V}$, faktor beban 0\% sampai $34,52 \%$, faktor ruginya $0-18,68 \%$. P1 $6600 \mathrm{VA}-200$ $\mathrm{kVA}, 220 / 380 \mathrm{~V}$, faktor bebannya $21,09 \%$, faktor ruginya $09,42 \%$. P2 di atas $200 \mathrm{kVA}$, faktor bebannya $10,07 \%$, faktor ruginya $03,72 \%$. P3/8,66 MVA faktor bebannya $24,71 \%$, faktor ruginya $11,68 \%$. Ini menjelaskan pula masih memungkinkan ada penambahan beban pelanggan oleh PLN. Sedangkan faktor rugi rata rata $8,89 \%$, menunjukkan daya PLN yang tersalur ke pelanggan belum maksimal.

TABEL 2. GOLONGAN DAYA TIAP-TIAP SEKTOR BEBAN PELANGGAN TARIF LISTRIK BEBAN PERHARI BULAN JUNI PADA SALURAN DISTRIBUSI FEEDER TRAFO 2

\begin{tabular}{|c|c|c|c|c|c|c|}
\hline $\begin{array}{c}\text { Tarif } \\
\text { Pelanggan }\end{array}$ & $\begin{array}{l}\text { Teg } \\
\text { (V) }\end{array}$ & $\begin{array}{l}\text { Daya } \\
\text { (VA) }\end{array}$ & $\begin{array}{c}\text { Beban } \\
\text { rata -rata } \\
(\mathbf{k W})\end{array}$ & $\begin{array}{c}\text { Beban } \\
\text { Puncak } \\
\text { (kW) }\end{array}$ & $\begin{array}{l}\text { Fb } \\
(\%)\end{array}$ & $\begin{array}{c}\mathrm{Fr} \\
(\%)\end{array}$ \\
\hline R.1/450 VA & 220 & 3.423 .600 & $1.647,48$ & $2.910,06$ & $\begin{array}{l}56,61 \\
\end{array}$ & 39,40 \\
\hline R.1/900 VA & & 5.287 .500 & $1.644,92$ & $4.494,37$ & 36,59 & 20,33 \\
\hline $\begin{array}{c}\text { R.1 M/900 } \\
\text { VA }\end{array}$ & & 35.528 .400 & $6.803,35$ & $30.199,14$ & 22,52 & 10,29 \\
\hline $\begin{array}{l}\text { R.1/1.300 } \\
\text { VA }\end{array}$ & & 41.068 .300 & $8.411,97$ & $34.908,05$ & 24,09 & 11,28 \\
\hline $\begin{array}{c}\text { R.1/2200 } \\
\text { VA }\end{array}$ & & 30.456 .800 & $7.104,8$ & $25.888,28$ & 27,44 & 13,49 \\
\hline $\begin{array}{c}\text { R.2/3.500 } \\
\text { VA - 5.500 } \\
\text { VA }\end{array}$ & & 18.919 .500 & $4.113,11$ & $16.081,57$ & 25,57 & 12,24 \\
\hline $\begin{array}{c}\text { R.3/6.600 } \\
\text { VA }>\end{array}$ & $\begin{array}{c}220- \\
380\end{array}$ & 8.273 .400 & $1.541,51$ & $7.032,39$ & 21,92 & 9,93 \\
\hline Jumlah R & & 142.957 .500 & $31.267,14$ & $121.513,86$ & & \\
\hline B.1/450 VA & 220 & 12.150 & 2,66 & $10.327,5$ & 0 & 0 \\
\hline B.1/900 VA & & 546.300 & 103,99 & 464,35 & 22,39 & 10,21 \\
\hline $\begin{array}{c}\text { B.1/1.300 } \\
\text { VA }\end{array}$ & & 1.215 .500 & 222,15 & $1.033,17$ & 21,50 & 9,68 \\
\hline $\begin{array}{c}\text { B.1/2.200 } \\
\text { VA - } 5.500 \\
\text { VA }\end{array}$ & & 10.209 .900 & $1.779,67$ & $8.678,41$ & 20,50 & 9,09 \\
\hline $\begin{array}{c}\text { B.2/6.600 } \\
\text { VA - } 200 \\
\text { kVA }\end{array}$ & $\begin{array}{c}220- \\
380\end{array}$ & 38.635 .100 & $6.837,27$ & $32.839,83$ & 20,82 & 9,27 \\
\hline $\begin{array}{c}\text { B. } 3 />200 \\
\text { kVA }\end{array}$ & & 36.202 .000 & $5.567,17$ & $30.771,70$ & 18,09 & 7,70 \\
\hline Jumlah B & & 86.820 .950 & $14.512,91$ & $84.114,96$ & & \\
\hline $\begin{array}{c}\mathrm{I} .1 / 3500 \\
\mathrm{VA}-14 \\
\mathrm{kVA}\end{array}$ & $\begin{array}{c}220- \\
380\end{array}$ & 21.100 & 0,92 & 17,93 & 5,13 & 1,71 \\
\hline $\begin{array}{c}\text { I. } 2 / 14 \mathrm{kVA} \\
-200 \mathrm{kV}\end{array}$ & & 795.500 & 175,994 & 676,17 & 26,02 & 12,53 \\
\hline $\begin{array}{c}\mathrm{I} .3 />200 \\
\mathrm{kVA}\end{array}$ & & 3.325 .000 & $1.025,5$ & $2.826,25$ & 36,28 & 20,09 \\
\hline Jumlah I & & 4.142 .500 & $1.202,41$ & $3.520,35$ & & \\
\hline P.1/450 VA & 220 & 450 & 0,24 & 382,5 & 0 & 0 \\
\hline $\begin{array}{c}\text { P.1/900 VA } \\
\text { P.1/1.300 } \\
\text { VA }\end{array}$ & & $\begin{array}{l}13.500 \\
18.200\end{array}$ & $\begin{array}{l}5,86 \\
4,71\end{array}$ & $\begin{array}{l}11,47 \\
15,47\end{array}$ & $\begin{array}{l}51,08 \\
30,44\end{array}$ & $\begin{array}{l}33,58 \\
15,61\end{array}$ \\
\hline $\begin{array}{c}\text { P. } 1 / 2.200 \\
\text { VA }-5.500 \\
\text { VA }\end{array}$ & & 104.600 & 18,86 & 88,91 & 21,21 & 9,50 \\
\hline $\begin{array}{c}\text { P. } 1 \text { / } 6.600 \\
\text { VA - } 200 \\
\text { kVA }\end{array}$ & $\begin{array}{l}220- \\
380\end{array}$ & 3.610 .000 & 752,42 & $3.068,50$ & 24,52 & 11,55 \\
\hline $\begin{array}{c}\text { P. } 2 />200 \\
\text { kVA }\end{array}$ & & 1.110 .000 & 130,57 & 943,50 & 13,83 & 5,47 \\
\hline $\begin{array}{c}\text { P.3/ 8,66 } \\
\text { MVA }\end{array}$ & & 5.136 .400 & $1.087,50$ & $4.365,94$ & 24,90 & 11,81 \\
\hline Jumlah P & & 9.993 .150 & $2.000,16$ & $6.114,64$ & & \\
\hline
\end{tabular}

Hasil Tabel 2 menunjukkan besarnya tarif pelanggan PLN rumah tangga R1 $450 \mathrm{VA}$ sampai 2200 VA, faktor bebannya $22,52 \%$ sampai $56,61 \%$, faktor ruginya $10,29 \%-39,40 \%$. R2 $3500 \mathrm{VA}$ sampai 5500 VA, faktor bebannya $25,57 \%$, faktor ruginya $12,24 \%$. R3 $6600 \mathrm{VA}, 220 / 380 \mathrm{~V}$, faktor bebannya $21,92 \%$, faktor ruginya $9,93 \%$. Ini memberikan pengertian bahwa pada sektor pelanggan rumah tangga masih memungkinkan untuk 
penambahan beban pelanggan. Sedangkan faktor rugi rata-rata $16,70 \%$ menunjukkan daya PLN yang tersalur ke pelanggan belum maksimal.

Sektor pelanggan bisnis B1 $450 \mathrm{VA} / 220 \mathrm{~V}$ sampai 5500 VA $/ 220 \mathrm{~V}$, mempunyai faktor beban $0 \%$ sampai $22,39 \%$, faktor ruginya $0 \%$ $10,21 \%$. B2 6600VA sampai 200 kVA, $220 \mathrm{~V} / 380 \mathrm{~V}$, faktor bebannya $20,82 \%$, faktor ruginya $9,27 \%$. B3 diatas $200 \mathrm{kVA}$ ke atas, faktor bebannya $18,09 \%$, faktor ruginya $7,70 \%$. Ini menjelaskan bahwa penambahan daya pelanggan bisnis masih dapat terlayani oleh PLN. Sedangkan faktor rugi rata - rata $7,65 \%$ menunjukkan daya PLN yang tersalur ke pelanggan belum maksimal.

Sektor pelanggan industri I1 $3500 \mathrm{VA}-14$ $\mathrm{kVA}$, faktor bebannya $5,13 \%$, faktor ruginya $1,71 \%$. I2 $14 \mathrm{kVA}-200 \mathrm{kVA}$, faktor bebanya $26,02 \%$, faktor ruginya $12,53 \%$. I3 di atas 200 $\mathrm{kVA}, 220 / 380 \mathrm{~V}$, faktor bebannya $36,28 \%$, faktor ruginya $20,09 \%$. Ini menjelaskan pula bahwa penambahan beban pelanggan industri masih memungkinkan oleh PLN. Sedangkan faktor rugi rata-rata $11,44 \%$ menunjukkan daya PLN yang tersalur ke pelanggan belum maksimal.

Sektor pemerintah P1 450 VA/220V, P1 900 VA/220V, P1 1300 VA/220V, P1 2200 VA/220V sampai $5500 \mathrm{VA} / 220 \mathrm{~V}$, faktor beban $0 \%$ sampai $51,08 \%$, faktor ruginya $0 \%-33,58 \%$. P1 6600 VA - $200 \mathrm{kVA}, 220 / 380 \mathrm{~V}$, faktor bebannya $24,52 \%$, faktor ruginya $11,55 \%$. P2 di atas $200 \mathrm{kVA}$, faktor bebannya $13,83 \%$, faktor ruginya $5,47 \%$. P3/8,66 MVA, 220/380V, faktor bebannya $24,90 \%$, faktor ruginya $11,81 \%$. Hal menjelaskan masih memungkinkan ada penambahan beban pelanggan oleh PLN. Sedangkan faktor rugi rata- rata $12,50 \%$ menunjukkan daya PLN yang tersalur ke pelanggan belum maksimal.

Hasil dari Tabel 3 menunjukkan besarnya tarif pelanggan PLN rumah tangga R1 450 VA sampai $2200 \mathrm{VA}$, faktor bebannya $21,44 \%$ sampai $60,83 \%$. Faktor ruginya $9,64 \%-44,14 \%$. R2 3500 VA sampai $5500 \mathrm{VA}$, faktor bebannya $24,63 \%$, faktor ruginya $10,35 \%$. R3 $6600 \mathrm{VA}$, $220 / 380$ volt, faktor bebannya $20,37 \%$, faktor ruginya $9 \%$. Ini memberikan pengertian bahwa pada sektor pelanggan rumah tangga tersebut tmasih memungkinkan untuk penambahan beban pelanggan atau ketersediaan daya PLN. Sedangkan faktor rugi $16,61 \%$ menunjukkan daya PLN yang tersalur ke pelanggan belum maksimal.
TABEL 3. GOLONGAN DAYA TIAP-TIAP SEKTOR BEBAN PELANGGAN TARIF LISTRIK BEBAN PERHARI BULAN JULI PADA SALURAN DISTRIBUSI FEEDER TRAFO 2

\begin{tabular}{|c|c|c|c|c|c|c|}
\hline $\begin{array}{c}\text { Tarif } \\
\text { Pelanggan }\end{array}$ & $\begin{array}{l}\text { Teg } \\
(V)\end{array}$ & $\begin{array}{l}\text { Daya } \\
\text { (VA) }\end{array}$ & $\begin{array}{c}\text { Beban } \\
\text { rata -rata } \\
(\mathrm{kW})\end{array}$ & $\begin{array}{c}\text { Beban } \\
\text { Puncak } \\
(\mathrm{kW})\end{array}$ & $\begin{array}{l}\text { Fb } \\
(\%)\end{array}$ & $\begin{array}{c}\mathbf{F r} \\
(\%)\end{array}$ \\
\hline $\begin{array}{c}\text { R.1/450 } \\
\text { VA }\end{array}$ & 220 & 3.423 .150 & 1.770 & $2.909,67$ & 60,83 & 44,14 \\
\hline $\begin{array}{c}\text { R.1/900 } \\
\text { VA }\end{array}$ & & 5.310 .000 & $1.635,77$ & $4.513,50$ & 36,24 & 20,06 \\
\hline $\begin{array}{c}\text { R. } 1 \mathrm{M} / 900 \\
\text { VA }\end{array}$ & & 35.716 .500 & $6.511,35$ & $30.359,02$ & 21,44 & 9,64 \\
\hline $\begin{array}{c}\text { R. } 1 / 1.300 \\
\text { VA }\end{array}$ & & 40.963 .000 & $8.014,57$ & $34.818,55$ & 23,01 & 10,60 \\
\hline $\begin{array}{c}\text { R. } 1 / 2200 \\
\text { VA }\end{array}$ & & 30.795 .600 & $6.793,47$ & $26.176,26$ & 25,95 & 12,49 \\
\hline $\begin{array}{c}\text { R. } 2 / 3.500 \\
\text { VA - } \\
5.500 \mathrm{VA}\end{array}$ & & 19.428 .000 & $4.068,09$ & $16.513,80$ & 24,63 & 10,35 \\
\hline $\begin{array}{c}\text { R.3/6.600 } \\
\text { VA }>\end{array}$ & $\begin{array}{c}220- \\
380 \\
\end{array}$ & 8.254 .100 & $1.429,84$ & $7.015,98$ & 20,37 & 9 \\
\hline Jumlah R & & 143.890 .350 & $30.223,09$ & $122.306,78$ & & \\
\hline $\begin{array}{l}\text { B.1/450 } \\
\text { VA }\end{array}$ & 220 & 12.150 & 3,05 & $10.327,5$ & 0 & 0 \\
\hline $\begin{array}{c}\text { B.1/900 } \\
\text { VA }\end{array}$ & & 545.400 & 108,37 & 463,59 & 23,37 & 10,83 \\
\hline $\begin{array}{c}\text { B. } 1 / 1.300 \\
\text { VA }\end{array}$ & & 1.218 .100 & 224,01 & $1.035,38$ & 21,63 & 9,74 \\
\hline $\begin{array}{c}\text { B. } 1 / 2.200 \\
\text { VA - } \\
5.500 \mathrm{VA}\end{array}$ & & 10.255 .800 & $1.793,79$ & $8.717,43$ & 20,57 & 9,13 \\
\hline $\begin{array}{c}\text { B. } 2 / 6.600 \\
\text { VA }-200 \\
k V A\end{array}$ & $\begin{array}{c}220- \\
380\end{array}$ & 38.712 .300 & $6.795,04$ & $32.905,45$ & 20,65 & 9,17 \\
\hline $\begin{array}{c}\text { B. } 3 />200 \\
\text { kVA }\end{array}$ & & 36.202 .000 & $5.898,61$ & $30.771,70$ & 19,16 & 8,30 \\
\hline Jumlah B & & 86.945 .750 & $14.822,87$ & $84.221,05$ & & \\
\hline $\begin{array}{c}\mathrm{I} .1 / 3500 \\
\mathrm{VA}-14 \\
\mathrm{kVA}\end{array}$ & $\begin{array}{c}220- \\
380\end{array}$ & 21.100 & 1,17 & 17,93 & 6,52 & 2,24 \\
\hline $\begin{array}{c}\mathrm{I} .2 / 14 \\
\mathrm{kVA}-200 \\
\mathrm{kV}\end{array}$ & & 795.500 & 162,10 & 676,17 & 23,97 & 11,20 \\
\hline $\begin{array}{c}\text { I. } 3 />200 \\
\text { kVA }\end{array}$ & & 3.325 .000 & 977,40 & $2.826,25$ & 34,58 & 18,73 \\
\hline Jumlah I & & 4.142 .500 & $1.140,67$ & $3.520,35$ & & \\
\hline $\begin{array}{c}\text { P.1/450 } \\
\text { VA }\end{array}$ & 220 & 450 & 0,27 & 382,5 & 0 & 0 \\
\hline $\begin{array}{c}\text { P.1/900 } \\
\text { VA }\end{array}$ & & 14.400 & 11,46 & 12,24 & 93,62 & 89,42 \\
\hline $\begin{array}{c}\text { P.1/1.300 } \\
\text { VA }\end{array}$ & & 18.200 & 4,72 & 15,47 & 30,51 & 13,57 \\
\hline $\begin{array}{c}\text { P.1/2.200 } \\
\text { VA - } \\
5.500 \mathrm{VA}\end{array}$ & & 104.600 & 20,94 & 88,91 & 23,55 & 10,93 \\
\hline $\begin{array}{c}P .1 / 6.600 \\
V A-200 \\
k V A\end{array}$ & $\begin{array}{c}220- \\
380\end{array}$ & 3.610 .000 & 791,44 & $3.068,50$ & 25,79 & 12,38 \\
\hline $\begin{array}{c}\text { P. } 2 \text { / > } 200 \\
\text { kVA }\end{array}$ & & 1.110 .000 & 160,13 & 943,50 & 16,97 & 7,09 \\
\hline $\begin{array}{c}\text { P.3/ 8,66 } \\
\text { MVA }\end{array}$ & & 5.136 .400 & $1.073,29$ & $4.365,94$ & 24,58 & 11,59 \\
\hline Jumlah P & & 9.994 .050 & $2.062,25$ & $8.887,06$ & & \\
\hline
\end{tabular}

Sektor pelanggan bisnis B1 $450 \mathrm{VA} / 220 \mathrm{~V}$ sampai $5500 \mathrm{VA} / 220 \mathrm{~V}$, mempunyai faktor beban 
$0 \%$ sampai $23,37 \%$, faktor ruginya $0 \%-10,83 \%$. B2 6600VA sampai $200 \mathrm{kVA}, 220 \mathrm{~V} / 380 \mathrm{~V}$, faktor bebannya $20,65 \%$, faktor ruginya $9,17 \%$ B3 200 $\mathrm{kVA}$ ke atas, faktor bebannya $19,16 \%$, faktor ruginya $8,30 \%$. Ini menjelaskan bahwa penambahan daya pelanggan bisnis masih dapat terlayani oleh PLN. Sedangkan faktor rugi rata rata 7,86\% menunjukkan daya PLN yang tersalur ke pelanggan belum maksimal.

Sektor pelanggan industri I1 $3500 \mathrm{VA}-14$ $\mathrm{kVA}$, faktor bebannya $6,52 \%$, faktor ruginya $2,24 \%$. I2 $14 \mathrm{kVA}-200 \mathrm{kVA}$, faktor bebanya $23,97 \%$, faktor ruginya $11,20 \%$. I3 di atas 200 kVA, $220 / 380 \mathrm{~V}$, faktor bebannya $34,58 \%$, faktor ruginya $18,73 \%$. Ini menjelaskan pula bahwa penambahan beban pelanggan industri masih memungkinkan oleh PLN. Sedangkan faktor rugi rata - rata $10,72 \%$ menunjukkan daya PLN yang tersalur ke pelanggan belum maksimal.

Sektor pemerintah P1 450 VA/220V, P1 900 VA/220V, P1 1300 VA/220V, P1 2200 VA/220V sampai $5500 \mathrm{VA} / 220 \mathrm{~V}$, faktor beban $0 \%$ sampai $93,62 \%$, faktor ruginya $0 \%-89,42 \%$. P1 $6600 \mathrm{VA}$ - $200 \mathrm{kVA}, 220 / 380 \mathrm{~V}$, faktor bebannya $25,79 \%$, faktor ruginya $12,38 \%$. P2 di atas $200 \mathrm{kVA}$, faktor bebannya $16,97 \%$, faktor ruginya $7,09 \%$. P3/8,66 MVA, 220/380V, faktor bebannya $24,58 \%$, dan faktor ruginya $11,59 \%$. Ini menjelaskan pula masih memungkinkan ada penambahan beban pelanggan oleh PLN. Sedangkan faktor rugi rata - rata $20,71 \%$ menunjukkan daya PLN yang tersalur ke pelanggan belum maksimal.

Hasil dari Tabel 4 menunjukkan besarnya tarif pelanggan PLN rumah tangga R1 450 VA sampai $2200 \mathrm{VA}$, faktor bebannya $21,55 \%$ sampai $62,36 \%$, faktor ruginya $9,70 \%-45,91 \%$. R2 3500 VA sampai $5500 \mathrm{VA}$, faktor bebannya $24,65 \%$, faktor ruginya $11,63 \%$. R3 $6600 \mathrm{VA}, 220 / 380$ volt, faktor bebannya $21,42 \%$, faktor ruginya $9,62 \%$. Ini memberikan pengertian bahwa pada sektor pelanggan rumah tangga tersebut masih memungkinkan untuk penambahan beban pelanggan atau ketersediaan daya PLN. Sedangkan faktor rugi rata-rata $17,28 \%$ menunjukkan daya PLN yang tersalur ke pelanggan belum maksimal.
TABEL 4. GOLONGAN DAYA TIAP-TIAP SEKTOR BEBAN PELANGGAN TARIF LISTRIK BEBAN PERHARI BULAN AGUSTUS PADA DISTRIBUSI FEEDER TRAFO 2

\begin{tabular}{|c|c|c|c|c|c|c|}
\hline $\begin{array}{c}\text { Tarif } \\
\text { Pelanggan }\end{array}$ & $\begin{array}{l}\text { Teg } \\
(\mathrm{V})\end{array}$ & $\begin{array}{l}\text { Daya } \\
\text { (VA) }\end{array}$ & $\begin{array}{c}\text { Beban } \\
\text { rata -rata } \\
(\mathrm{kW})\end{array}$ & $\begin{array}{c}\text { Beban } \\
\text { Puncak } \\
(\mathrm{kW})\end{array}$ & $\begin{array}{c}\text { Fb } \\
(\%)\end{array}$ & $\begin{array}{c}\mathbf{F r} \\
(\%)\end{array}$ \\
\hline $\begin{array}{c}\text { R.1/450 } \\
\text { VA }\end{array}$ & 220 & 3.416 .850 & $1.811,15$ & $2.904,32$ & 62,36 & 45,91 \\
\hline $\begin{array}{c}\text { R.1/900 } \\
\text { VA }\end{array}$ & & 5.334 .300 & $1.661,77$ & $4.534,15$ & 36,65 & 20,39 \\
\hline $\begin{array}{c}\text { R.1 M/900 } \\
\text { VA }\end{array}$ & & 35.826 .300 & $6.562,76$ & $30.452,35$ & 21,55 & 9,70 \\
\hline $\begin{array}{c}\text { R.1/1.300 } \\
\text { VA }\end{array}$ & & 40.729 .000 & $8.193,05$ & $34.619,65$ & 23,66 & 11 \\
\hline $\begin{array}{c}\text { R. } 1 / 2200 \\
\text { VA }\end{array}$ & & 31.284 .000 & $7.002,63$ & $26.591,40$ & 26,33 & 12,74 \\
\hline $\begin{array}{c}\text { R. } 2 / 3.500 \\
\text { VA - } \\
5.500 \mathrm{VA}\end{array}$ & & 20.573 .400 & $4.310,70$ & $17.487,39$ & 24,65 & 11,63 \\
\hline $\begin{array}{c}\text { R.3/6.600 } \\
\text { VA }>\end{array}$ & $\begin{array}{c}220- \\
380 \\
\end{array}$ & 8.283 .800 & $1.508,51$ & $7.041,23$ & 21,42 & 9,62 \\
\hline Jumlah R & & 145.447 .650 & $031.050,57$ & $123.630,49$ & & \\
\hline $\begin{array}{c}\text { B.1/450 } \\
\text { VA }\end{array}$ & 220 & 12.150 & 3,19 & $10.327,5$ & 0 & 0 \\
\hline $\begin{array}{c}\text { B. } 1 / 900 \\
\text { VA }\end{array}$ & & 545.400 & 111,19 & 463,59 & 23,98 & 11,21 \\
\hline $\begin{array}{c}\text { B. } 1 / 1.300 \\
\text { VA }\end{array}$ & & 1.216 .800 & 225,87 & $1.034,28$ & 21,83 & 9,87 \\
\hline $\begin{array}{c}\text { B. } 1 / 2.200 \\
\text { VA - } \\
5.500 \mathrm{VA}\end{array}$ & & 10.270 .500 & $1.830,18$ & $8.729,92$ & 20,96 & 9,35 \\
\hline $\begin{array}{c}\text { B. } 2 / 6.600 \\
\text { VA - } 200 \\
\text { kVA }\end{array}$ & $220-$ & 38.918 .900 & $7.096,11$ & $33.081,06$ & 21,45 & 9,65 \\
\hline $\begin{array}{c}\text { B. } 3 />200 \\
\mathrm{kVA}\end{array}$ & & 36.202 .000 & $6.023,42$ & $30.771,70$ & 19,57 & 8,54 \\
\hline Jumlah B & & 87.165 .750 & $15.289,96$ & $84.408,05$ & & \\
\hline $\begin{array}{c}\mathrm{I} .1 / 3500 \\
\mathrm{VA}-14 \\
\mathrm{kVA}\end{array}$ & $\begin{array}{c}220- \\
380\end{array}$ & 21.100 & 0,89 & 17,93 & 4,96 & 1,65 \\
\hline $\begin{array}{c}\mathrm{I} .2 / 14 \\
\mathrm{kVA}-200 \\
\mathrm{kV}\end{array}$ & & 795.500 & 155,69 & 676,17 & 23,02 & 10,60 \\
\hline $\begin{array}{c}\mathrm{I} .3 />200 \\
\mathrm{kVA}\end{array}$ & & 3.325 .000 & 972,47 & $2.826,25$ & 34,40 & 18,60 \\
\hline Jumlah I & & 4.142 .500 & $1.129,05$ & $3.520,35$ & & \\
\hline $\begin{array}{c}\text { P.1/450 } \\
\text { VA }\end{array}$ & 220 & 450 & 0,24 & 382,5 & 0 & 0 \\
\hline $\begin{array}{c}\text { P.1/900 } \\
\text { VA }\end{array}$ & & 14.400 & 10,53 & 12,24 & 86,02 & 77,59 \\
\hline $\begin{array}{c}\text { P.1/1.300 } \\
\text { VA }\end{array}$ & & 18.200 & 4,23 & 15,47 & 27,34 & 13,42 \\
\hline $\begin{array}{c}\text { P.1/2.200 } \\
\mathrm{VA}- \\
5.500 \mathrm{VA}\end{array}$ & & 104.600 & 20,68 & 88,91 & 23,25 & 10,75 \\
\hline $\begin{array}{c}\mathrm{P} .1 / 6.600 \\
\mathrm{VA}-200 \\
\mathrm{kVA}\end{array}$ & 380 & - 3.610 .000 & 789,31 & $3.068,50$ & 25,72 & 12,33 \\
\hline $\begin{array}{c}\text { P. } 2 />200 \\
k V A\end{array}$ & & 1.110 .000 & 137,06 & 943,50 & 14,52 & 5,82 \\
\hline $\begin{array}{c}\text { P.3/ 8,66 } \\
\text { MVA }\end{array}$ & & 5.136 .400 & $1.046,27$ & $4.365,94$ & 23,96 & 11,19 \\
\hline Jumlah P & & 9.994 .050 & $2.008,32$ & $8.877,06$ & & \\
\hline
\end{tabular}

Sektor pelanggan bisnis B1 $450 \mathrm{VA} / 220 \mathrm{~V}$ sampai $5500 \mathrm{VA} / 220 \mathrm{~V}$, mempunyai faktor beban $0 \%$ sampai $23,98 \%$, faktor ruginya $0 \%-11,21 \%$. B2 
6600VA sampai $200 \mathrm{kVA}, 220 \mathrm{~V} / 380 \mathrm{~V}$, faktor bebannya $21,45 \%$, faktor ruginya $9,65 \%$. B3 diatas $200 \mathrm{kVA}, 220 / 380 \mathrm{~V}$ ke atas, faktor bebannya $19,57 \%$, faktor ruginya $8,54 \%$. Ini menjelaskan bahwa penambahan daya pelanggan bisnis masih dapat terlayani oleh PLN. Sedangkan faktor rugi rata - rata $8,10 \%$ menunjukkan daya PLN yang tersalur ke pelanggan belum maksimal.

Sektor pelanggan industri I1 $3500 \mathrm{VA}-14$ $\mathrm{kVA}$, faktor bebannya $4,96 \%$, faktor ruginya $1,65 \%$. I2 $14 \mathrm{kVA}-200 \mathrm{kVA}$, faktor bebanya $23,02 \%$, faktor ruginya $10,60 \%$ dan I3 di atas 200 $\mathrm{kVA}, 220 / 380 \mathrm{~V}$, faktor bebannya $34,40 \%$, faktor ruginya $18,60 \%$. Ini menjelaskan pula bahwa penambahan beban pelanggan industri masih memungkinkan oleh PLN. Sedangkan faktor rugi rata - rata $10,28 \%$ menunjukkan daya PLN yang tersalur ke pelanggan belum maksimal.

Sektor pemerintah P1 $450 \mathrm{VA} / 220 \mathrm{~V}, \mathrm{P} 1900$ VA/220V, P1 1300 VA/220V, P1 2200 VA/220V sampai $5500 \mathrm{VA} / 220 \mathrm{~V}$, faktor beban $0 \%$ sampai $86,02 \%$, faktor ruginya $0 \%-77,59 \%$. P1 $6600 \mathrm{VA}$ $-200 \mathrm{kVA}, 220 / 380 \mathrm{~V}$, faktor bebannya $25,72 \%$, faktor ruginya $12,33 \%$. P2 di atas 200kVA, $220 / 380 \mathrm{~V}$, faktor bebannya $14,52 \%$, faktor ruginya $5,82 \%$. P3/8,66 MVA, 220/380V, faktor bebannya $23,96 \%$, dan faktor ruginya $11,19 \%$. Ini menjelaskan pula masih memungkinkan ada penambahan beban pelanggan oleh PLN. Sedangkan faktor rugi rata - rata $18,72 \%$ menunjukkan daya PLN yang tersalur ke pelanggan belum maksimal.

\section{B. Pembahasan}

Kebutuhan beban dari suatu wilayah tergantung dari wilayah, penduduk dan standar kehidupan masyarakat, ini merupakan salah satu bagian studi dari suatu pengembangan sistim kelistrikan untuk masa yang akan datang, demikian pula tarif dan harga daya dan sebagainya. Perusahaan listrik negara adalah salah suatu perusahaan BUMN yang dipercayakan untuk menyiapkan dan melaksanakan perkiraan kebutuhan daya listrik baik wilayah, daerah maupun nasional.

Tenaga listrik yang ada disalurkan ke berbagai beban listrik seperti perumahan (domestic) yang penggunaannya berupa penerangan dan alat - alat rumah tangga lainnya maupun motor - motor listrik yang berdaya kecil, beban listrik pada bisnis hotel, rumah makan, dan lain sebagainya, beban listrik pada industri berupa mesin listrik baik berkapasitas sedang maupun yang besar. Sedangkan komersial/pemerintah, beban listrik digunakan seperti penerangan, AC (air conditioning) dan lain sebagainya.
Penelitian adalah salah satu metodologi dalam menentukan perkiraan akan kebutuhan beban listrik pada suatu wilayah atau daerah, dimana salah satu yang menjadi ukuran akan penggunaan atau pemakaian daya listrik setiap bulan atau setiap hari dapat kita lihat dari besarnya faktor beban yang ada.

Saluran distribusi untuk sektor panakkukang makassar terdiri dari tiga feeder yaitu feeder trafo 1, feeder trafo 2, dan feeder trafo 3 demikian pula pada sektor yang lain di kota makassar yang terdiri dari banyak feeder-feeder lainnya.

Peneliti memilih salah satu sektor panakkukang makassar pada feeder terbesar ada pada feeder trafo 2 yang saluran distribusinya mensuplai tenaga listrik keberbagai beban pelanggan rumah tangga, bisnis, industri, komersial/pemerintah.

Melihat dari faktor beban harian selama 4 bulan, yang diperoleh pada penelitian untuk wilayah / sektor panakukang makassar pada feeder trafo 2 untuk pelanggan rumah tangga beban 450 VA sampai 6600 VA faktor bebannya hampir tetap saja yaitu $30,52 \%$ - 32,50\% atau rata rata $31,11 \%$, pelanggan bisnis yaitu $17,21 \%-21,35 \%$ atau rata rata $18,52 \%$, industri faktor beban yaitu $21,37 \%$ - $22,47 \%$ atau rata rata $21,58 \%$, dan faktor beban pemerintah yaitu $18,87 \%$ $30,71 \%$ atau rata rata $25,49 \%$. Secara keseluruhan faktor beban harian pada bulan mei sampai agustus 2020, rata rata pemakaian beban listrik oleh pelanggan masih rendah, Ini berarti memungkin masih dapat melayani pemakaian atau permintaan daya yang tersedia dari PLN atau masih ada peluang menambah permintaan pelanggang baru, dimana faktor beban PLN tertinggi baru mencapai 47,5\%. dan maksimal $80 \%$.

Faktor Rugi Rugi daya pada saluran distribusi disebabkan oleh antara lain adalah jenis penghantar, besar kecil suatu penghantar, maupun panjang penghantar atau saluran. Faktor rugi-rugi beban merupakan rugi-rugi sebagai fungsi waktu, berubah sesuai dengan waktu dan kuadrat beban. Oleh karena itu, faktor rugi-rugi ini tidak dapat ditentukan langsung dari faktor beban. Berdasarkan pengalaman dan percobaan yang dilakukan Buller dan Woodrow diperoleh persamaan empiris, yaitu:

$$
\mathrm{f}_{\mathrm{r}}=0.3 f b+0.7 f b^{2}
$$

Hasil yang diperoleh selama 4 bulan menunjukkan besarnya faktor rugi untuk saluran pelanggan rumah tangga rata rata $17,23 \%$ dan faktor rugi untuk saluran pelanggan bisnis rata rata besarnya $8,35 \%$, untuk pelanggan industri faktor ruginya rata rata $10,63 \%$, dan pelanggan pada pemerintah faktor ruginya rata rata $15,2 \%$.

Susut daya atau rugi daya listrik adalah berkurangnya pasokan daya yang dikirim oleh PLN 
kepada penerima atau tidak terpakainya daya listrik 0leh pelanggang listrik sehingga menyebabkan daya yang hilang pada saluran listrik tersebut. Ini artinya bahwa PLN mengalami kerugian finansial apabila faktor rugi besar. Olehnya itu estimasi penyaluran listrik ke beban atau pelanggan listrik, harus sebaik mungkin dipertimbangkan.

\section{KESIMPULAN}

1. Perubahan faktor beban sektor pelanggan listrik pada saluran distribusi feeder trafo 2 panakkukang makassar berfluktuasi secara priodik tergantung besar permintaan daya listrik dan pemakaian daya listrik PLN. Perubahan faktor beban tersebut, masih memenuhi standar operasional yang diperbolehkan, karena faktor beban pada setiap pelanggan listrik PLN baru mencapai $18,52 \%$ sampai $31,11 \%$. Berdasarkan informasi pihak PLN UP3 Makassar Selatan, faktor beban tertinggi hanya $47,5 \%$ dan maksimal $80 \%$. Jadi memungkinkan penambahan beban pelanggan listrik PLN, maksimal sebesar 32,5\%.

2. Rata-rata besar faktor rugi pada setiap pelanggan tersebut yaitu $8,35 \%$ sampai $17,23 \%$. Ini tergantung besarnya perubahan faktor beban, yang disebabkan oleh besarnya beban pelanggan atau adanya permintaan tambahan beban pelanggan listrik PLN, artinya makin mendekati faktor beban maksimum, faktor rugi pada PLN kecil, karena daya yang disalurkan dapat terserap seluruhnya kepada pihak pemakai.

\section{DAFTAR PUSTAKA}

[1] W. D. Stevenson Jr, "Analisa Sistem Tenaga terjemahan Ir," Kamal Idris, cetakan keempat, Jakarta: Erlangga, 1994.

[2] T. Sen, "Electrical and Production Load Factors," Texas A \& M University, 2010.

[3] N. Doerry, "Electric power load analysis," Naval Eng. J., vol. 124, no. 4, pp. 45-48, 2012.

[4] M. Dilek, "Integrated design of electrical distribution systems: phase balancing and phase prediction case studies," Virginia Tech, 2000.

[5] P. Dr, Sugiyono, Metode Penelitian Kuantitatif Kualitatif dan $R \& D . \quad \mathrm{CV}$. Alfabeta, Bandung, 2008. 